Article

\title{
Preparation of Chitosan/Magnetic Porous Biochar as Support for Cellulase Immobilization by Using Glutaraldehyde
}

\author{
Haodao Mo and Jianhui Qiu * \\ Department of Machine Intelligence and Systems Engineering, Faculty of Systems Science and Technology, \\ Akita Prefectural University, Yurihonjo 015-0055, Japan; D18S003@akita-pu.ac.jp \\ * Correspondence: qiu@akita-pu.ac.jp
}

Received: 19 October 2020; Accepted: 11 November 2020; Published: 12 November 2020

\begin{abstract}
In this work, porous biochar was obtained from sugarcane bagasse by alkali activation and pyrolysis and then magnetized with $\gamma-\mathrm{Fe}_{2} \mathrm{O}_{3}$ by calcination. After functionalization with chitosan and activation with glutaraldehyde, the as-prepared chitosan/magnetic porous biochar served as a support to immobilize cellulase by covalent bonds. The immobilization amount of cellulase was $80.5 \mathrm{mg}$ cellulase/g support at $\mathrm{pH} 5$ and $25^{\circ} \mathrm{C}$ for $12 \mathrm{~h}$ of immobilization. To determine the enzymatic properties, $1 \%$ carboxymethyl cellulose sodium (CMC) (dissolved in $0.1 \mathrm{M}$ buffer) was considered as a substrate for hydrolysis at different $\mathrm{pH}$ values (3-7) and temperatures $\left(30-70{ }^{\circ} \mathrm{C}\right)$ for $30 \mathrm{~min}$. The results showed that the optimum $\mathrm{pH}$ and temperature of the free and immobilized cellulase did not change, which were $\mathrm{pH} 4$ and $60^{\circ} \mathrm{C}$, respectively. The immobilized cellulase had a relatively high activity recovery of 73.0\%. However, it also exhibited a higher Michaelis-Menten constant $\left(K_{\mathrm{m}}\right)$ value and a slower maximum reaction velocity $\left(\mathrm{V}_{\max }\right)$ value compared to the free enzyme. In the reusability assay, the immobilized cellulase showed initial glucose productivity of $330.9 \mathrm{mg}$ glucose $/ \mathrm{g}$ CMC and remained at $86.0 \%$ after 10 uses. In conclusion, the chitosan/magnetic porous biochar has great potential applications as a support for enzyme immobilization.
\end{abstract}

Keywords: enzyme immobilization; covalent bonding; porous biochar; chitosan; magnetic composites

\section{Introduction}

In recent years, using biomass for bioethanol production has garnered great interest. Cellulose and hemicellulose can be hydrolyzed to reducing sugars, and then the sugars can be fermented into ethanol. For the process of hydrolyzing lignocellulosic materials, the use of strong acids or alkalis increases the burden on the environment and equipment, but enzymatic hydrolysis would not. Therefore, enzymatic hydrolysis of lignocellulosic should be a greenway to produce fermentable reducing sugars [1-3]. Cellulase, a composite enzyme, is mainly composed of endo-l, 4- $\beta$-D-glucanase, exo-l, $4-\beta$-D-glucanase, and $\beta$-glucosidase. Its classification is based on attacking the depolymerization stage of the substrate. Endoglucanases randomly hydrolyze the glycosidic bonds in the amorphous regions of cellulose to produce oligomers with several degrees of polymerization. Then, exoglucanase hydrolyzes the $\beta-1,4$-glycosidic bond of the oligomer to produce cellobiose. Finally, cellobiose is degraded to glucose by $\beta$-glucosidase [4]. However, some factors limit the application of free cellulases, such as changes in $\mathrm{pH}$, temperature, and ionic strength, product inhibition, and difficulty in recovering from the reaction medium. Therefore, it is meaningful to improve the stability and reusability of cellulase $[5,6]$. Several methods can be used for enhancing the stability of the enzyme, such as protein engineering, chemical modification, and immobilization $[7,8]$. Among them, immobilization has more advantages in heterogeneous enzymatic reactions and reusability [9]. 
Immobilization on a solid support can improve an enzyme's stability and makes it easier to recover said enzyme from the medium and soluble substrate, as previously proven $[10,11]$. For a solid substrate, immobilization can also provide a way to improve the stability and reusability of enzymes. Covalent bonding can provide a stable structure for an enzyme, and an immobilized enzyme with a magnetic base can be easily separated from the respective slurry by a magnetic bar [12]. In recent years, various types of solid supports have been used for enzyme immobilization, such as natural clays $[13,14]$, gels $[15,16]$, and porous materials. Usually, natural materials have good biocompatibility and rich functional groups, but the low surface area limits their application. Therefore, porous materials have a large specific surface area that could provide more space for enzyme immobilization. Mesoporous silica [17], metal-organic framework materials [18], and zeolites [19] are popular supports in enzyme immobilization. However, their preparations are complicated and normally require precision, which increases the costs.

Biochar, a solid porous particle obtained by the pyrolysis of biomass in the absence of oxygen [20], is popular in soil amendments [21], wastewater treatments [22], and electrode materials [23]. Simultaneously, it is emerging as a promising support for immobilizing enzymes. Porous biochar has a high specific surface area $\left(\sim 1600 \mathrm{~m}^{2} / \mathrm{g}\right)$ and different types of pore structures [24,25]. Compared to other materials (e.g., mesoporous silica, zeolite, graphene, and metal-organic framework), porous biochar has the advantages of abundant sources, a simple preparation method, and a cheap cost. However, the insufficient number of reactive and hydrophilic groups and inconvenient recovery limit its application to the immobilization of hydrophilic enzymes.

In order to conveniently and quickly recycle and reuse enzymes, magnetic base material has been paid much attention because it can be easily separated from the reaction system by simply applying a magnet. [26-29]. Co-precipitation and hydrothermal methods are commonly used to prepare magnetic base materials. However, it is difficult to use these two methods to prepare magnetic biochar because there are few functional groups on the surface of activated porous biochar. If the iron ions are firstly dispersed and attached to the biochar, the magnetic particles can be uniformly grown in the biochar after calcination. This is a good strategy to prepare magnetic biochar. In order to improve the biocompatibility of magnetic biochar, chitosan is usually used to modify the supports because it has good hydrophilic, biocompatible, and non-toxicity properties. In addition, chitosan can allow amino groups to covalently bind with enzymes [30-32].

Covalent attachment is a very convenient method for enzymatic immobilization. It has been proven to be more efficient and can provide more stable biocatalysis [33]. Glutaraldehyde should be the most widely used cross-linking agent because it is facile, efficient, and can improve the stability of an enzyme by multipoint or multisubunit immobilization. A support with primary amino groups can be activated by glutaraldehyde; then, the glutaraldehyde-activated support reacts with the primary amino groups of the enzyme. For immobilized cellulase, the glutaraldehyde-activated carrier may be sterically hindered because of its spacer arms. However, it can be considered a hetero-functional support that can provide chemical reaction groups and anion exchange, and it offers the highest reactivity with the amino groups of a protein [34]. Epoxy- and di-vinyl-sulfone (DVS)-activated supports are also popular for enzyme immobilization via multipoint covalent attachment, but they have some limitations; for example, the low reactivity of epoxy-activated supports [34] and the low activity recovery of DVS-activated supports [35]. In addition, dithiocarbamate (DTC) is of great interest as a new functional group for covalent immobilization. The amination carrier is firstly modified with carbon disulfide to generate a DTC group, and is then covalently bonded to the amine group on the surface of an enzyme [36,37]. Though this is an effective technique and DTC has a shorter spacer arm, carbon disulfide is an enzyme inhibitor and this method still needs further discussion. Therefore, glutaraldehyde was selected as the covalent agent for cellulase immobilization in this work.

Based on the above, the main objective of this work was to use porous biochar (obtained from agricultural waste sugarcane bagasse) as a basis to obtain chitosan/magnetic porous biochar after magnetization and functionalization. Then, it was used as a support for cellulase immobilization via 
glutaraldehyde. The structure and morphology of the support were characterized, and the enzymatic properties of the free and immobilized enzymes were evaluated in hydrolyzed carboxymethyl cellulose sodium, including optimum $\mathrm{pH}$ and temperature, kinetic parameters, and reusability.

\section{Materials and Methods}

\subsection{Materials}

Sugarcane bagasse was produced in Guangxi, China. Potassium hydroxide $(\mathrm{KOH})$, hydrochloric acid $(\mathrm{HCl} ; 35-37 \mathrm{wt} \%)$, ferric chloride hexahydrate $\left(\mathrm{FeCl}_{3} \cdot 6 \mathrm{H}_{2} \mathrm{O}\right)$, ferrous chloride tetrahydrate $\left(\mathrm{FeCl}_{2} \cdot 4 \mathrm{H}_{2} \mathrm{O}\right)$, chitosan $(\mathrm{CS})$, acetic acid (HAc), sodium acetate (NaAc), glutaraldehyde (GA; $\left.25 \%, v / v\right)$, and carboxymethyl cellulose sodium (CMC) were purchased from Nacalai Tesque, Inc. (Tokyo, Japan). Cellulase (pale yellow powder) was bought from Meiji Seika Pharma Co., Ltd. (Tokyo, Japan).

\subsection{Support Preparation}

First of all, the porous biochar was prepared from the sugarcane bagasse by pyrolysis with $\mathrm{KOH}$ activation [38]. After boiled processing at $95^{\circ} \mathrm{C}$ for $8 \mathrm{~h}$, impurities on the surface of the sugarcane bagasse were removed. The dry pretreated sugarcane bagasse was mixed with $\mathrm{KOH}$ and ethanol at a ratio of $1 \mathrm{~g} / 1 \mathrm{~g} / 12 \mathrm{~mL}$. The mixture was thoroughly mixed $\left(500 \mathrm{r} / \mathrm{min}, 60^{\circ} \mathrm{C}\right.$ for $5 \mathrm{~h}$ ) and then dried $\left(60^{\circ} \mathrm{C}\right.$ for $\left.12 \mathrm{~h}\right)$. Then, it was pyrolyzed in a tube furnace with nitrogen protection at $800{ }^{\circ} \mathrm{C}$ for $2 \mathrm{~h}$ (heating rate: $10^{\circ} \mathrm{C} / \mathrm{min}$ ). After grinding and soaking in a $1.5 \mathrm{M} \mathrm{HCl}$ solution to remove ash and alkali, the porous biochar was washed with distilled water and dried $\left(80^{\circ} \mathrm{C}\right.$ for $\left.24 \mathrm{~h}\right)$, and then denoted as $\mathrm{C}$.

In order to improve the combination of the porous biochar and the magnetic base, a calcination method was used [39]. First, $0.1 \mathrm{~g}$ of porous biochar, $0.2 \mathrm{mmol}$ of $\mathrm{FeCl}_{3} \cdot 6 \mathrm{H}_{2} \mathrm{O}$, and $0.1 \mathrm{mmol}$ of $\mathrm{FeCl}_{2} \cdot 4 \mathrm{H}_{2} \mathrm{O}$ were dispersed in $2 \mathrm{~mL}$ of an ethanol solution. The mixture was calcined in a tube furnace at $500{ }^{\circ} \mathrm{C}$ for $1 \mathrm{~h}$ under nitrogen protection (heating rate: $10^{\circ} \mathrm{C} / \mathrm{min}$ ). Finally, magnetic porous biochar was obtained and denoted as $\mathrm{C} / \gamma-\mathrm{Fe}_{2} \mathrm{O}_{3}$.

Before cellulase immobilization, it is very effective and convenient to modify biochar with chitosan to improve its biocompatibility and to increase its surface functional groups. First, $0.5 \mathrm{~g}$ of $\mathrm{C} / \gamma-\mathrm{Fe}_{2} \mathrm{O}_{3}$ was added to $25 \mathrm{~mL}$ of a $1 \%(v / v)$ acetic acid solution (containing $50 \mathrm{mg}$ of chitosan) with strong stirring at room temperature for $30 \mathrm{~min}$; then, it was mixed with $25 \mathrm{~mL}$ of a $1 \mathrm{M} \mathrm{NaOH}$ solution. The products were recovered by a magnet and washed with distilled water 5 times, before being denoted as $\mathrm{C} / \gamma-\mathrm{Fe}_{2} \mathrm{O}_{3} @ \mathrm{CS}$.

\subsection{Cellulase Immobilization}

Here, $\mathrm{C} / \gamma-\mathrm{Fe}_{2} \mathrm{O}_{3} @ \mathrm{CS}$ was activated by glutaraldehyde. The support obtained above was dispersed in $25 \mathrm{~mL}$ of a $2.5 \%(v / v$, dissolved in distilled water, $\mathrm{pH} 7)$ glutaraldehyde solution at room temperature for $2.5 \mathrm{~h}$. Afterward, the activated support was washed with distilled water and a $0.1 \mathrm{M} \mathrm{HAc}-\mathrm{NaAc}$ buffer solution ( $\mathrm{pH}$ 5) 3 times.

In the cellulase immobilization process, the activated support was put into $25 \mathrm{~mL}$ of a $4 \mathrm{mg} \mathrm{mL}^{-1}$ cellulase solution ( $400 \mathrm{mg}$ of cellulase powder was dissolved in $100 \mathrm{~mL}$ of a $0.1 \mathrm{M} \mathrm{pH} 5 \mathrm{HAc}-\mathrm{NaAc}$ buffer solution at room temperature) with low stirring at room temperature for $12 \mathrm{~h}$. The products were washed with a $0.1 \mathrm{M} \mathrm{pH} 5 \mathrm{HAc}-\mathrm{NaAc}$ buffer solution 3 times and recovered by a magnet. The immobilized cellulase was stored at $4{ }^{\circ} \mathrm{C}$, and the supernatant was used to determine the concentration of residual cellulase by the Bradford protein assay method [40]. The cellulase immobilization amount and yield were calculated by the following equation:

$$
\text { Cellulase immobilization amount }=\mathrm{C}_{0} \mathrm{~V}_{0}-\mathrm{C}_{1} \mathrm{~V}_{1}
$$

where $C_{0}, C_{1}, V_{0}$, and $V_{1}$ refer to the concentration and volume before and after cellulase immobilization, respectively. 


\subsection{Characterizations}

X-ray diffraction (XRD) was used to determine the structure and composition of the samples, while a scanning electron microscope (SEM; Hitachi S-4300, Tokyo, Japan) was used to analyze the morphologies of the particles. The magnetism of the samples was characterized by a vibrating-sample magnetometer (VSM; Riken Denshi Co. Ltd., Tokyo, Japan). Brunauer-Emmett-Teller (BET; Micromeritics, Norcross, GA, USA) analysis determined the average pore size, the BET surface area, and the total pore volume of the samples using the nitrogen adsorption method at $77 \mathrm{~K}$. The chemical structures of the samples were confirmed by Fourier transform infrared spectroscopy (FT-IR; IRT-7000, Jasco, Tokyo, Japan). The amount of cellulase and reducing sugar were determined using a UV spectrophotometer (UV-vis; U-5100, Tokyo, Japan).

\subsection{Activity Assay}

The enzyme activity was determined using the IUPAC method [41]. The steps of the activity assay were as follows: For the free cellulase, $0.5 \mathrm{~mL}$ of cellulase solution $\left(0.02 \mathrm{mg} \mathrm{mL}^{-1}\right.$, dissolved in a $0.1 \mathrm{M}$ HAc-NaAc buffer) was reacted with $0.5 \mathrm{~mL}$ of $1 \%(\mathrm{~m} / \mathrm{v}) \mathrm{CMC}$ for $30 \mathrm{~min}$; for the immobilized cellulase, the samples (containing $0.2 \mathrm{mg}$ of cellulase) were dispersed in $10 \mathrm{~mL}$ of a $0.1 \mathrm{M}$ buffer solution and mixed with $10 \mathrm{~mL}$ of a $1 \%(\mathrm{~m} / \mathrm{v})$ CMC solution (both of them were preheated) for $30 \mathrm{~min}$. The supernatant was used for measuring the amount of reducing sugars via the dinitrosalicylic acid (DNS) colorimetric method. The cellulase activity (IU/mg cellulase) was defined as the production of $\mu$ mol of glucose per minute through the hydrolysis of CMC by cellulase. To evaluate the effects of $\mathrm{pH}$ and temperature on cellulase activity, the hydrolysis reactions were carried out at different $\mathrm{pH}$ (3.0-7.0 at $\left.50{ }^{\circ} \mathrm{C}\right)$ and temperatures $\left(30-70{ }^{\circ} \mathrm{C}\right.$ at $\left.\mathrm{pH} 4\right)$.

\subsection{Kinetic Assay}

This assay was performed by measuring the glucose produced by the cellulase hydrolyzation of different concentrations of substrates at the optimum $\mathrm{pH}$ and temperature for $5 \mathrm{~min}$. The samples (containing $0.2 \mathrm{mg}$ of cellulase) were dispersed in $10 \mathrm{~mL}$ of a $0.1 \mathrm{M} \mathrm{pH} 4 \mathrm{HAc}-\mathrm{NaAc}$ buffer solution and mixed with $10 \mathrm{~mL}$ of different concentrations of a CMC solution $\left(5,7.5,10,12.5\right.$, and $15 \mathrm{~g} \mathrm{~L}^{-1}$ of a $0.1 \mathrm{M} \mathrm{pH} 4 \mathrm{HAc}-\mathrm{NaAc}$ buffer solution) at $60^{\circ} \mathrm{C}$ for $5 \mathrm{~min}$. The Michaelis-Menten constant $\left(\mathrm{K}_{\mathrm{m}}\right)$ and the maximum reaction velocity $\left(\mathrm{V}_{\max }\right)$ were determined by Lineweaver-Burk plots.

\subsection{Reusability Assay}

Based on the viewpoint of practical applications, a longer hydrolysis time was used to determine the reusability of the immobilized cellulase [5]. The immobilized cellulase containing $3 \mathrm{mg}$ of cellulase was mixed with $10 \mathrm{~mL}$ of a $1 \%(\mathrm{~m} / \mathrm{v}) \mathrm{CMC}$ solution $(\mathrm{pH} 4)$ for $24 \mathrm{~h}$ at $60^{\circ} \mathrm{C}$. Then, the immobilized cellulase was recycled by a magnet and added to a fresh CMC solution for another cycle. The reusability was evaluated by the production of reducing sugars from each cycle, and the reusability assay was repeated 10 times.

\section{Results}

\subsection{Characterization of Supports and Cellulases}

Figure 1 shows the XRD patterns of the biochar (black curve), biochar $/ \gamma-\mathrm{Fe}_{2} \mathrm{O}_{3}$ (red curve), biochar $/ \gamma-\mathrm{Fe}_{2} \mathrm{O}_{3} @$ chitosan (blue curve), and immobilized cellulase (pink curve). There are two broad diffraction peaks that appear at $23.1^{\circ}$ and $43.4^{\circ}$ in the pattern of Figure $1 \mathrm{a}$, which should be the (002) and (100) planes of graphite [42]. Based on the patterns of the biochar $/ \gamma-\mathrm{Fe}_{2} \mathrm{O}_{3}$, all of the diffraction peaks can be indexed to $\gamma-\mathrm{Fe}_{2} \mathrm{O}_{3}$ according to JCPDS no. 39-1346 [43], which indicates that $\gamma-\mathrm{Fe}_{2} \mathrm{O}_{3}$ grew on the surface of the porous biochar. After coating chitosan and immobilizing cellulase, the crystal of $\gamma-\mathrm{Fe}_{2} \mathrm{O}_{3}$ did not change, as indicated by the blue and purple curves. 


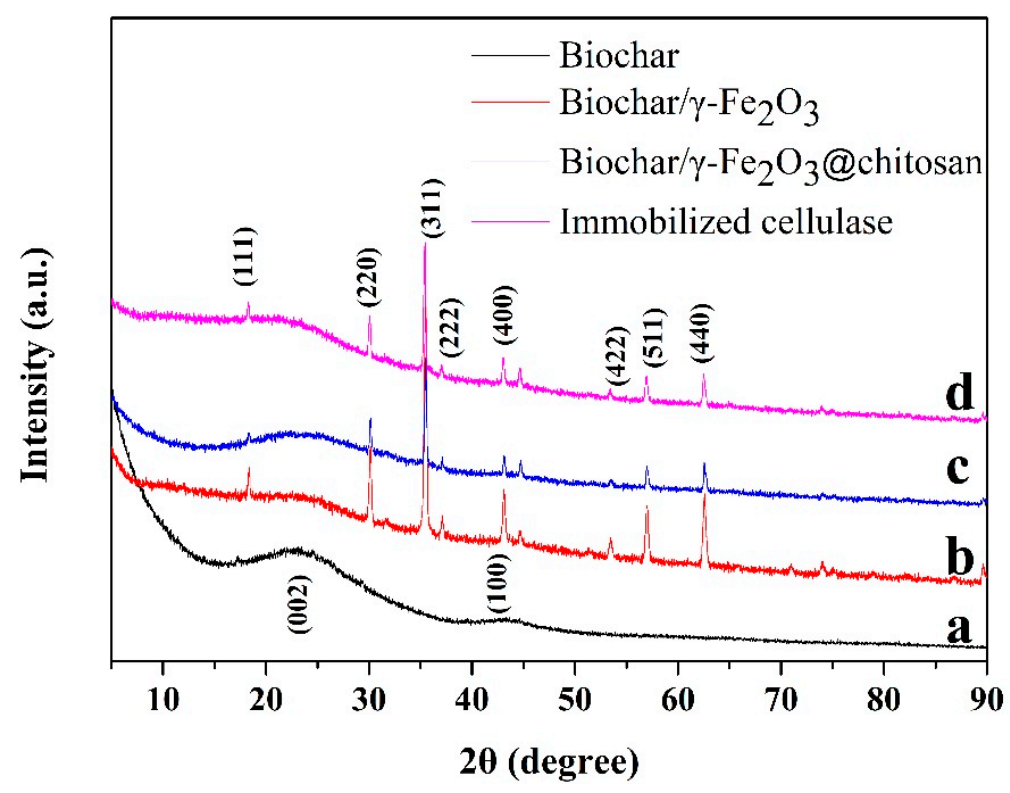

Figure 1. The X-ray diffraction (XRD) patterns of biochar (a, black curve), biochar $/ \gamma-\mathrm{Fe}_{2} \mathrm{O}_{3}$ (b, red curve), biochar $/ \gamma-\mathrm{Fe}_{2} \mathrm{O}_{3} @$ chitosan (c, blue curve), and immobilized cellulase (d, pink curve).

The SEM images of the porous biochar and its magnetic composites are given in Figure 2. A porous structure can be found in porous biochar (Figure 2d), which has a smooth surface. After mixing with the iron and calcination, a lot of crystals grew on the surface of the porous biochar, indicating that the porous biochar can be well combined with magnetic particles by calcination. As per Figure $2 \mathrm{c}, \mathrm{f}$, a thin layer can be seen covering the surface of the biochar and magnetic particles following chitosan modification, and the macropore structure of the porous biochar was well maintained, which was helpful for the substrate to diffuse into the pores so as to improve the enzymatic performance.
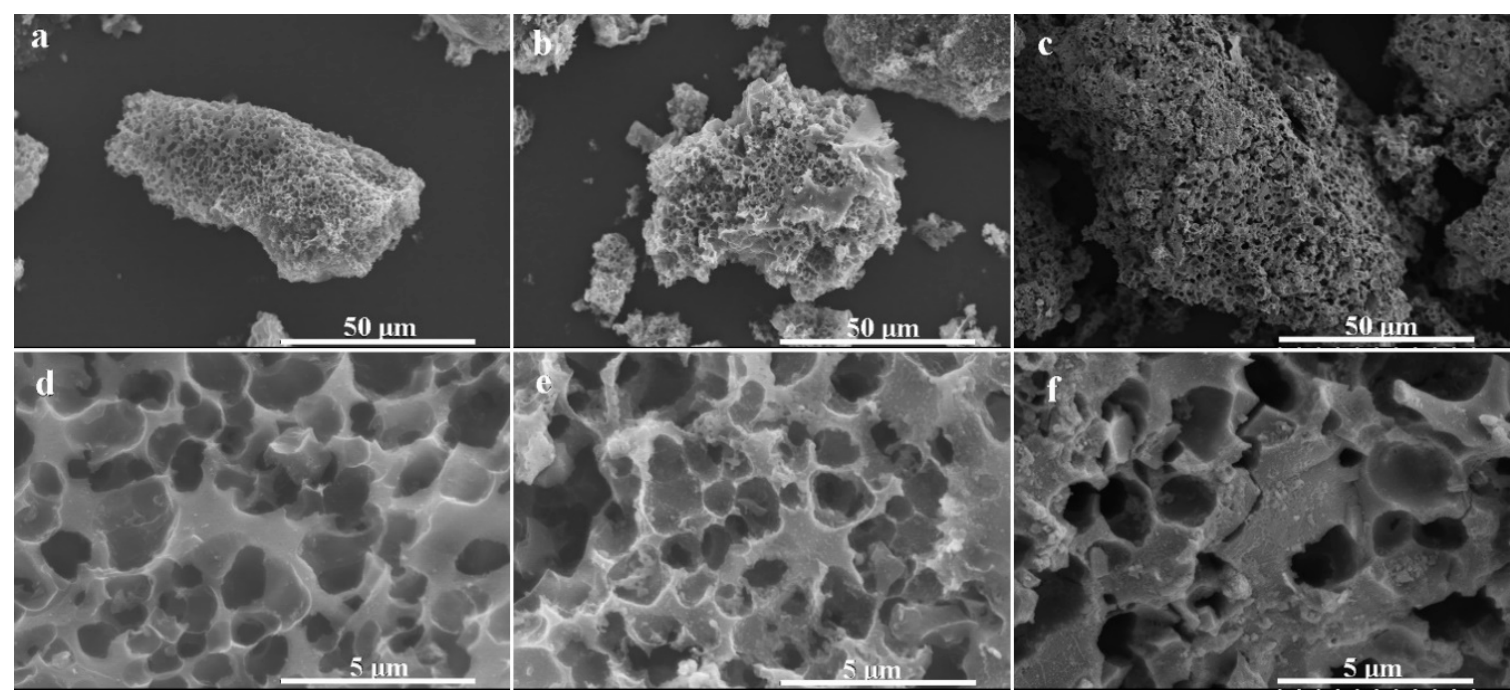

Figure 2. Scanning electron microscopy (SEM) images of (a,d) biochar, $(\mathbf{b}, \mathbf{e})$ biochar $/ \gamma-\mathrm{Fe}_{2} \mathrm{O}_{3}$, and (c,f) biochar $/ \gamma-\mathrm{Fe}_{2} \mathrm{O}_{3} @$ chitosan. (d-f) Magnified images at the center of the materials in $(\mathbf{a}-\mathbf{c})$, respectively.

Figure 3 shows the magnetization curves of the biochar $/ \gamma-\mathrm{Fe}_{2} \mathrm{O}_{3}$ and biochar $/ \gamma-\mathrm{Fe}_{2} \mathrm{O}_{3} @$ chitosan at room temperature. It can be seen that the saturation magnetization of the biochar $/ \gamma-\mathrm{Fe}_{2} \mathrm{O}_{3}$ was $0.81 \mathrm{emu} / \mathrm{g}$. However, the saturation magnetization of the biochar $/ \gamma-\mathrm{Fe}_{2} \mathrm{O}_{3} @$ chitosan decreased to $0.67 \mathrm{emu} / \mathrm{g}$. This could have been caused by the coating of non-magnetic chitosan on the surface of the 
biochar $/ \gamma-\mathrm{Fe}_{2} \mathrm{O}_{3}$ and the weight conversion of the coating. It can be clearly seen from the photos in Figure 3 that most of the biochar $/ \gamma-\mathrm{Fe}_{2} \mathrm{O}_{3} @$ chitosan could be easily recovered by a magnet.

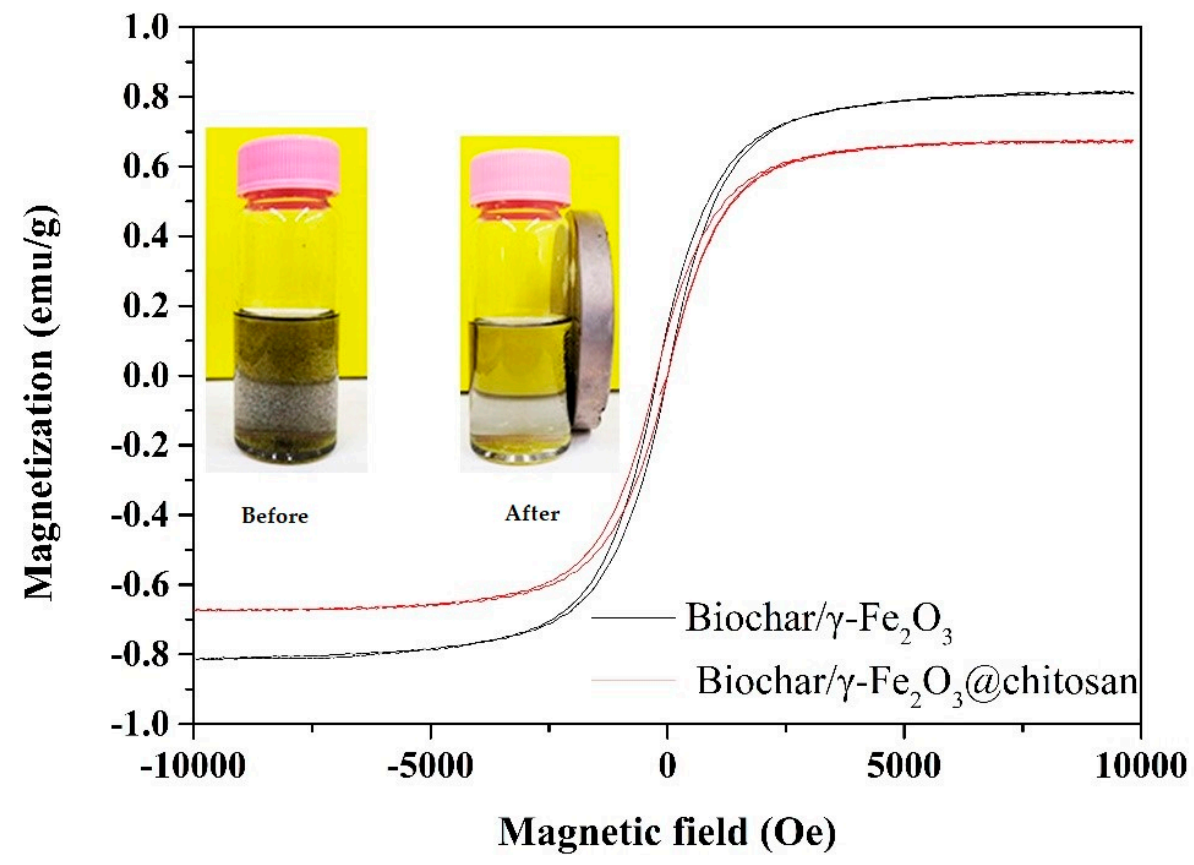

Figure 3. Vibrating-sample magnetometer (VSM) magnetization curves of the biochar $/ \gamma-\mathrm{Fe}_{2} \mathrm{O}_{3}$ (black curve) and biochar $/ \gamma-\mathrm{Fe}_{2} \mathrm{O}_{3} @$ chitosan (red curve). The insets show the state of the biochar $/ \gamma-\mathrm{Fe}_{2} \mathrm{O}_{3} @$ chitosan before and after being recovered by a magnet.

Figure 4 shows the $\mathrm{N}_{2}$ adsorption-desorption isotherm (Figure $4 \mathrm{a}$ ) and the pore size distribution (Figure $4 \mathrm{~b}$ ) of the porous biochar, biochar $/ \gamma-\mathrm{Fe}_{2} \mathrm{O}_{3}$, and biochar $/ \gamma-\mathrm{Fe}_{2} \mathrm{O}_{3} @$ chitosan using the $\mathrm{BJH}$ method. The nitrogen adsorption-desorption isotherms of the samples exhibit a combination of type I and IV shapes according to the IUPAC classification, which explains that the samples contain both micropores and mesopores [39]. However, the $\mathrm{N}_{2}$ adsorption capacity of the biochar decreased after modification with $\gamma-\mathrm{Fe}_{2} \mathrm{O}_{3}$ and chitosan. The average pore size, BET surface area, and total pore volume of the porous biochar, biochar $/ \gamma-\mathrm{Fe}_{2} \mathrm{O}_{3}$, and biochar $/ \gamma-\mathrm{Fe}_{2} \mathrm{O}_{3} @$ chitosan are given in Table 1. After modification of the magnetic base material and chitosan, the BET surface area of the support reduced from 1595.7 to $271.6 \mathrm{~m}^{2} \mathrm{~g}^{-1}$. This is because, during the process of modifying the support, the modification coated the surface of the porous biochar and the inner wall of the pores, thereby blocking a part of the mesopores of the biochar. After modification, the average pore size of the sample increased. This is because the iron ions adhered to the biochar and then the magnetic iron oxide crystals grew after calcination. During this process, some of the small pores were blocked, so the average pore size of the biochar $/ \gamma-\mathrm{Fe}_{2} \mathrm{O}_{3}$ became larger than that of the biochar. After chitosan modification, flocculent chitosan covered the surface of the sample, causing some of the small pores to become blocked, leading to an increase in the average pore size. 

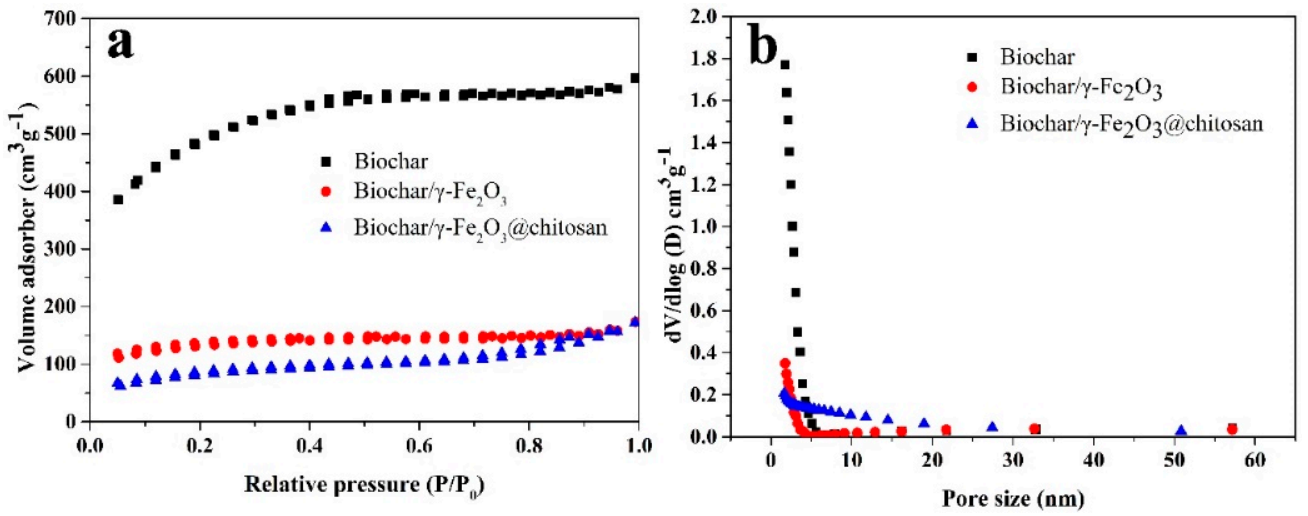

Figure 4. (a) The $\mathrm{N}_{2}$ adsorption-desorption isotherm and the (b) pore size distribution of the porous biochar (black square), biochar $/ \gamma-\mathrm{Fe}_{2} \mathrm{O}_{3}$ (red ball), and biochar $/ \gamma-\mathrm{Fe}_{2} \mathrm{O}_{3} @$ chitosan (blue triangle) using the BJH method.

Table 1. The average pore size, Brunauer-Emmett-Teller (BET) surface area, and total pore volume of the biochar, biochar $/ \gamma-\mathrm{Fe}_{2} \mathrm{O}_{3}$, and biochar $/ \gamma-\mathrm{Fe}_{2} \mathrm{O}_{3} @$ chitosan.

\begin{tabular}{|c|c|c|c|}
\hline Samples & Average Pore Size (nm) & $\begin{array}{l}\text { BET Surface Area } \\
\left(\mathrm{m}^{2} \mathrm{~g}^{-1}\right)\end{array}$ & $\begin{array}{l}\text { Total Pore Volume } \\
\left(\mathrm{cm}^{3} \mathrm{~g}^{-1}\right)\end{array}$ \\
\hline Biochar & 2.6 & 1595.7 & 0.923 \\
\hline Biochar $/ \gamma-\mathrm{Fe}_{2} \mathrm{O}_{3}$ & 3.6 & 421.3 & 0.119 \\
\hline Biochar $/ \gamma-\mathrm{Fe}_{2} \mathrm{O}_{3} @$ chitosan & 3.8 & 271.6 & 0.208 \\
\hline
\end{tabular}

The chemical functional group of the biochar (black curve), biochar $/ \gamma-\mathrm{Fe}_{2} \mathrm{O}_{3}$ (red curve), biochar $/ \gamma-\mathrm{Fe}_{2} \mathrm{O}_{3} @$ chitosan (green curve), immobilized cellulase (pink curve), and free cellulase (blue curve) samples was determined by FT-IR. As shown in Figure 5, the C-O stretching vibration of the porous biochar was found at $1100 \mathrm{~cm}^{-1}$ [44]. For the biochar $/ \gamma-\mathrm{Fe}_{2} \mathrm{O}_{3} @$ chitosan, the methylene stretching vibrations at 2924 and $2856 \mathrm{~cm}^{-1}$ were attributed to the chitosan layer [45]. Moreover, amide II stretching vibrations of the cellulase at 1648 and $1560 \mathrm{~cm}^{-1}$ were found in the immobilized enzyme, which suggests that the cellulase was successfully immobilized onto the support.

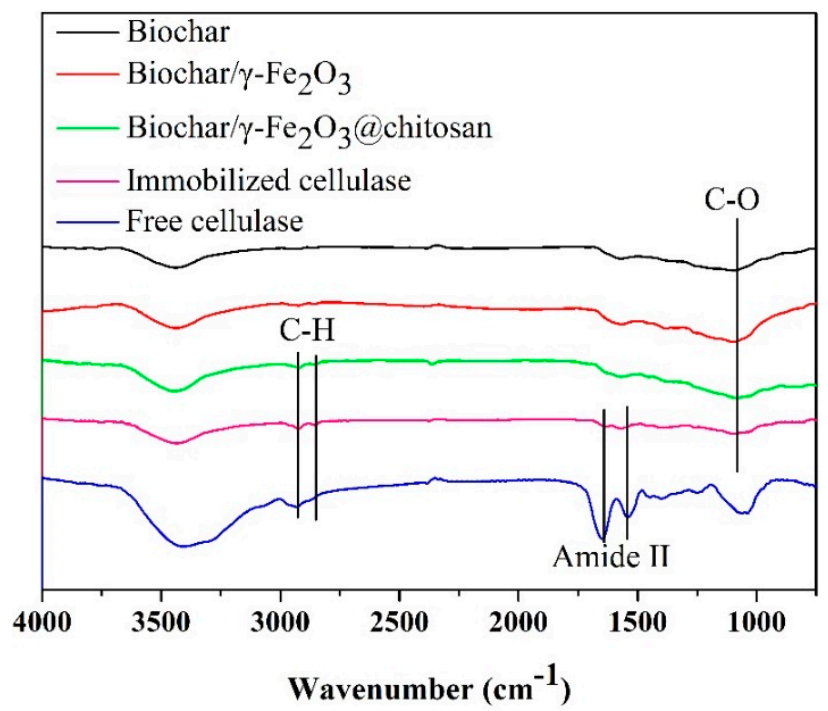

Figure 5. Fourier transform infrared spectroscopy (FT-IR) spectra of the biochar (black curve), biochar $/ \gamma-\mathrm{Fe}_{2} \mathrm{O}_{3}$ (red curve), biochar $/ \gamma-\mathrm{Fe}_{2} \mathrm{O}_{3} @$ chitosan (green curve), immobilized cellulase (pink curve), and free cellulase (blue curve). 


\subsection{Effect of $p H$ and Temperature on Cellulase Activity}

According to the Bradford protein assay method and equation calculations, the amount and rate of cellulase immobilization was $80.5 \mathrm{mg}$ cellulase/g support and $40.25 \%$, respectively. In this method, multi-point or multi-subunit immobilization is such a slow process that the cellulase could be adsorbed onto the glutaraldehyde-activated support before the end. After three washings with buffer, the adsorbed cellulase was desorbed from the support. Moreover, the acidic condition was not ideal for multi-point immobilization [34]; however, the cellulase was stable under this condition.

After immobilization, the structure of cellulase may be altered, which would change the accessibility of the active site, stability, and specificity [46]. Therefore, it is necessary to investigate the influence of $\mathrm{pH}$ and temperature on the activity between free and immobilized enzymes. Figure 6a shows that the relative activity of the free and immobilized cellulase had similar trends and that the optimal $\mathrm{pH}$ was 4 . This could suggest that there are few alterations of the cellulase after immobilization. In addition, the immobilized cellulase showed higher relative activity than the free cellulase at $\mathrm{pH} 3$. Under acidic conditions, the protonation of chitosan was easy and it was possible to interact with more CMC [45]. This means that during the hydrolysis process, the CMC concentration around the immobilized enzyme could have been higher than that of the free one at a lower $\mathrm{pH}$, which could have promoted the hydrolysis process. The influence of the relative activity on the thermal characteristics of both enzymes was determined to be in the range of $30-70{ }^{\circ} \mathrm{C}$ at $\mathrm{pH}$. The results are shown in Figure $6 \mathrm{~b}$ and the highest activity appeared at $60^{\circ} \mathrm{C}$. At 30 and $40^{\circ} \mathrm{C}$, the relative activity of the immobilized cellulase was slightly lower than that of the free enzyme. The enzyme, after being covalently immobilized (compared to the free enzyme), was fixed and could not freely contact/react with the substrate in the medium. Therefore, the substrate should diffuse into the support to reach the active site of the immobilized enzyme. Moreover, the product should diffuse away from the active site to facilitate further binding of the substrate [47,48]. The diffusion coefficient is a function of temperature, increases as temperature increases. When the temperature was low, the diffusion coefficient of CMC was weak; therefore, the immobilized cellulase showed lower relative activity. However, at a high temperature, the immobilized cellulase showed higher stability. This could be because a covalent bond between the support and the enzyme protects the conformation of cellulase during heating.
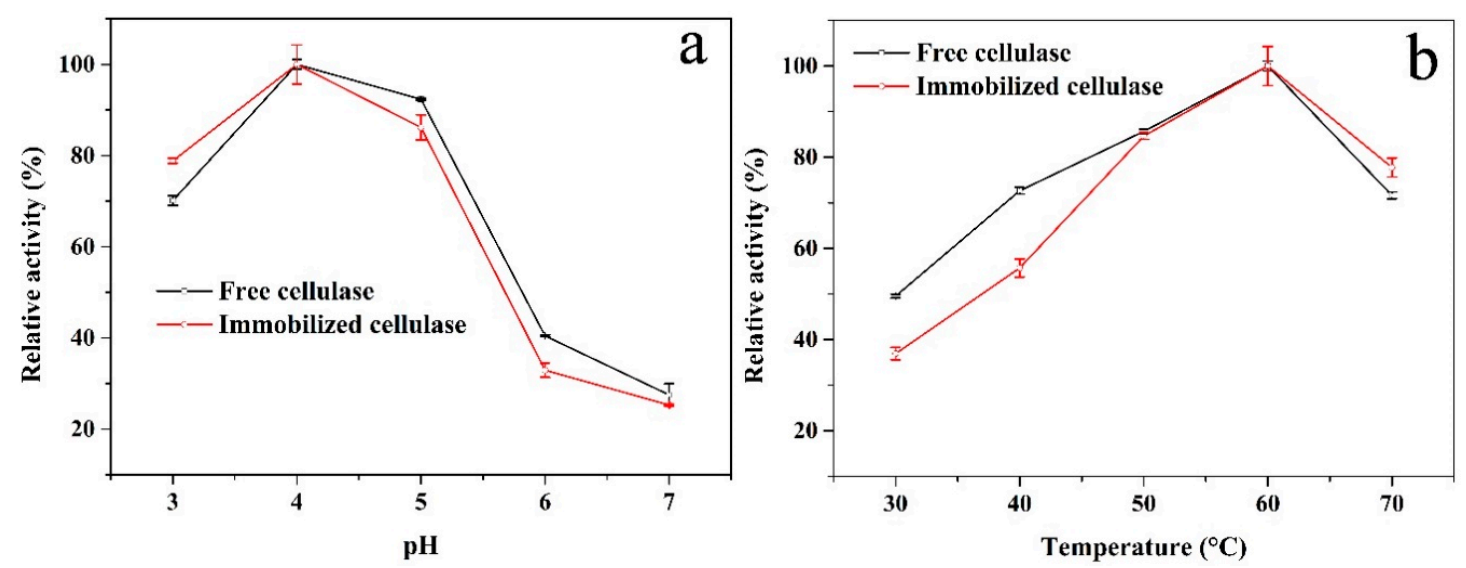

Figure 6. Influences of (a) $\mathrm{pH}$ and (b) temperature on the relative activity of the free (black curve) and immobilized (red curve) cellulase.

In order to further investigate the factors affecting the cellulase activity, the immobilized and free enzymes were used to hydrolyze a $1 \% \mathrm{CMC}$ solution for $50 \mathrm{~min}$ at $50{ }^{\circ} \mathrm{C}$ with different $\mathrm{pH}$ levels $(3,4$, and 5$)$, as well as at $\mathrm{pH} 4$ with different temperatures $\left(50,60\right.$, and $\left.70^{\circ} \mathrm{C}\right)$. The concentration of glucose in the supernatant was measured every $10 \mathrm{~min}$. As shown in Figure 7, both the immobilized and free cellulase had the highest concentrations of glucose at $\mathrm{pH} 4$. The glucose produced by the free 
enzyme hydrolysis of CMC was higher than that of the immobilized enzyme. However, the change in $\mathrm{pH}$ had a greater impact on the free enzyme's hydrolysis process of CMC. Moreover, the inhibitory effect on enzyme activity was more obvious at $\mathrm{pH}$. The immobilized enzyme showed a relatively stable state under these conditions, which could be attributed to the covalent bonds and the CS layer, confirming the above analysis. Figure 8 shows the effect of temperature on the hydrolysis process. As the temperature increased (from 50 to $70^{\circ} \mathrm{C}$ ), the diffusion coefficient of $\mathrm{CMC}$ became stronger and it was easier for the CMC to diffuse into the active sites of the enzyme. For the free enzyme (Figure 8b), the concentration of glucose showed a higher level at 60 and $70{ }^{\circ} \mathrm{C}$ during the initial hydrolysis. However, this enzyme may denature and its original structure could be destroyed at an excessively high temperature, which would inhibit the enzyme activity. This is why the growth rate of the glucose concentration quickly returned to being flat at $70{ }^{\circ} \mathrm{C}$. In Figure 8a, compared to the free enzyme, the glucose amount of the immobilized cellulase increased steadily during the 50-min continuous reaction. This is because this enzyme is less susceptible to temperature-induced conformational changes after covalent immobilization [49], meaning that cellulase can maintain its structure during the hydrolysis process.
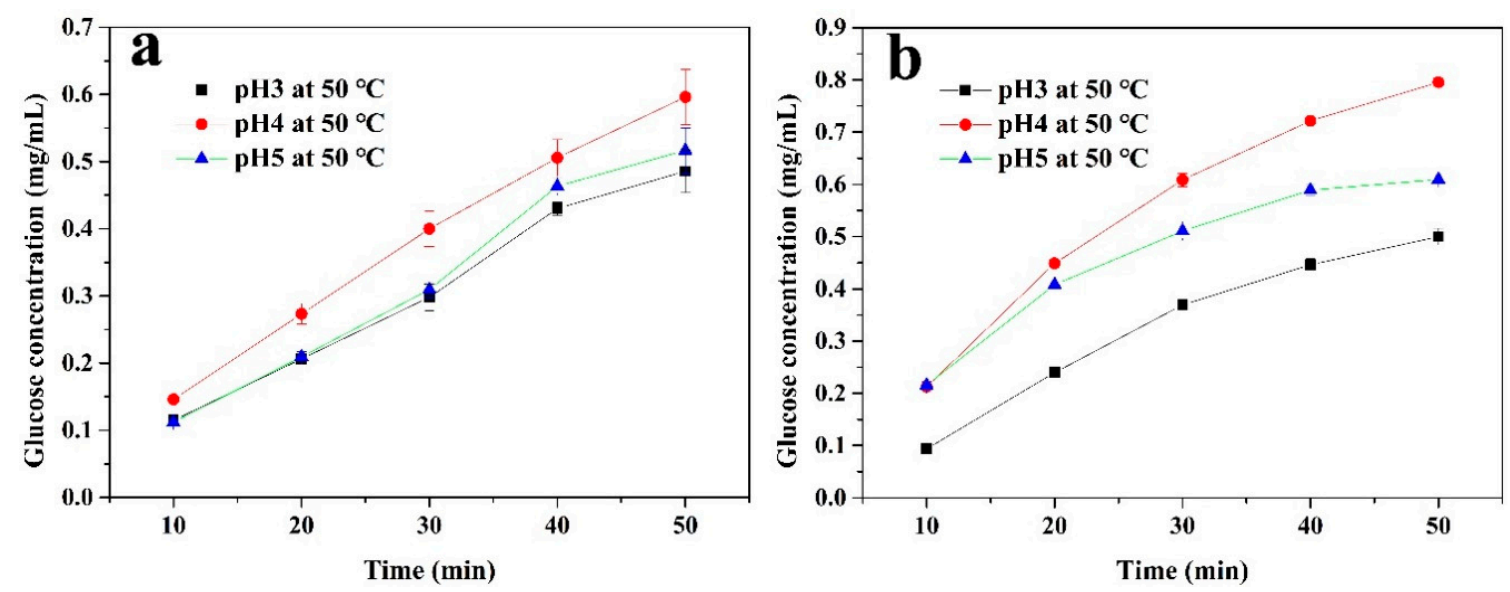

Figure 7. The glucose produced from the (a) immobilized and (b) free cellulase by hydrolyzing a $1 \%$ carboxymethyl cellulose sodium (CMC) solution at $50{ }^{\circ} \mathrm{C}$ with different $\mathrm{pH}$ values for $50 \mathrm{~min}$.
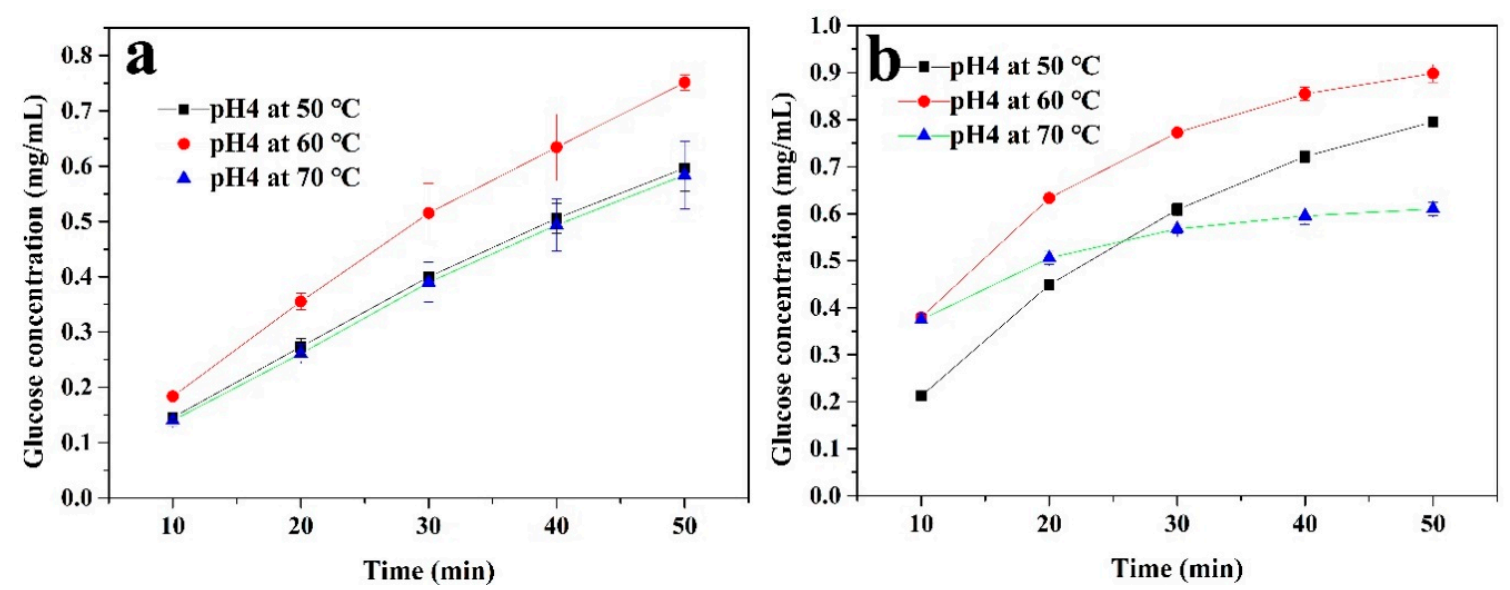

Figure 8. The glucose produced from the (a) immobilized and (b) free cellulase by hydrolyzing a $1 \%$ $\mathrm{CMC}$ solution at $\mathrm{pH} 4$ with different temperatures for $50 \mathrm{~min}$.

\subsection{Effect of CMC Concentrations on Cellulase Activity}

The Michaelis-Menten constant $\left(\mathrm{K}_{\mathrm{m}}\right)$ and maximum reaction velocity $\left(\mathrm{V}_{\max }\right)$ of enzymes are important kinetic parameters for determining the tightness of a substrate and enzyme binding and the 
speed of the enzymatic reaction. The $K_{m}$ and $V_{\max }$ were determined by Lineweaver-Burk plots shown in Figure 9 and Table 2. The $K_{m}$ value of the free and immobilized cellulase was 8.298 and $12.134 \mathrm{~g} \mathrm{~L}^{-1}$, while their $\mathrm{V}_{\max }$ values were 0.102 and $0.059 \mathrm{~g} \mathrm{~L}^{-1} \mathrm{~min}^{-1}$, respectively. The increase in $\mathrm{K}_{\mathrm{m}}$ and the decrease in $\mathrm{V}_{\max }$ indicates that the binding tightness between the immobilized enzyme and substrate decreased compared to that of the free enzyme. This is because of the steric hindrance generated by the support [45].

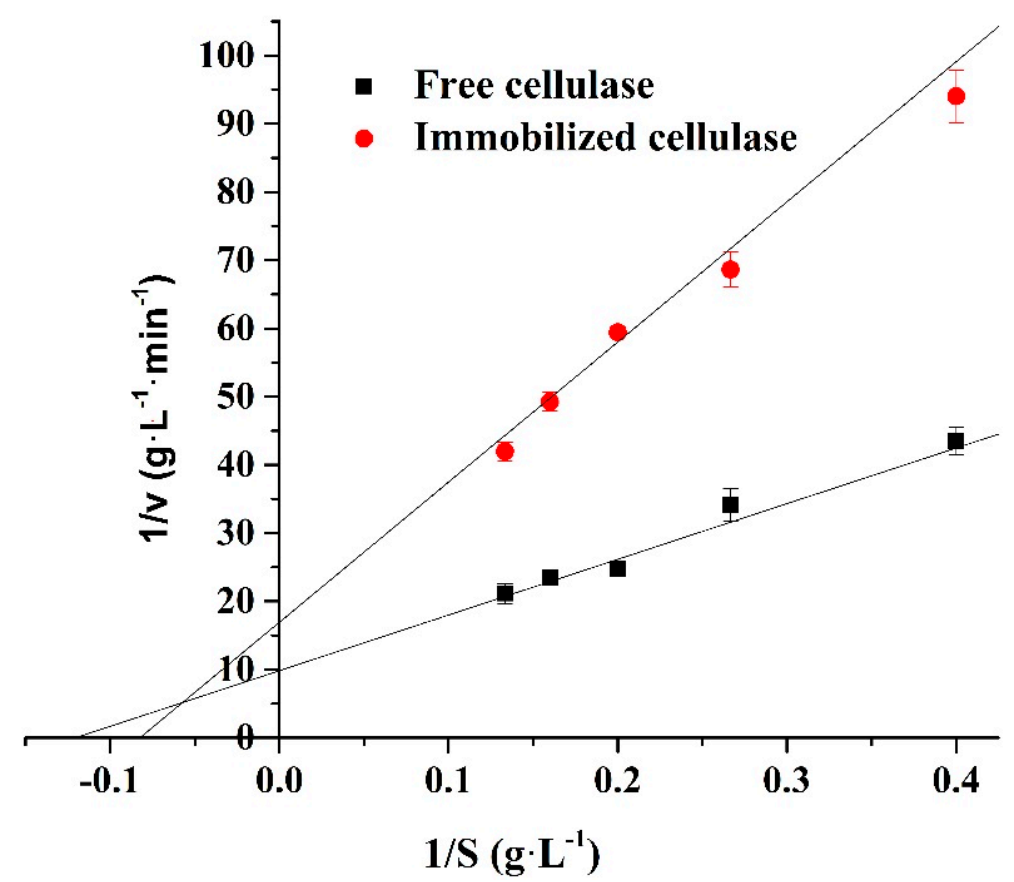

Figure 9. Effect of the $\mathrm{CMC}$ concentration on the cellulase activity (the cellulase concentration was $0.01 \mathrm{mg} / \mathrm{mL}$ at $\mathrm{pH} 4$ and $60^{\circ} \mathrm{C}$ for $5 \mathrm{~min}$ ). $1 / \mathrm{V}$ is the reciprocal of the enzymatic reaction rate and $1 / \mathrm{S}$ is the reciprocal of the substrate concentration.

Table 2. Kinetic parameters of the free and immobilized cellulase.

\begin{tabular}{ccc}
\hline & $\mathbf{K m}\left(\mathbf{g ~ L}^{-\mathbf{1}}\right)$ & Vmax $\left(\mathbf{g ~ L}^{-\mathbf{1}} \mathbf{~ m i n}^{-\mathbf{1}}\right)$ \\
\hline Free cellulase & 8.298 & 0.102 \\
Immobilized cellulase & 12.134 & 0.059 \\
\hline
\end{tabular}

\subsection{Reusability of the the Immobilized Cellulase}

The reusability of immobilized enzymes is one of the key factors for lowering the cost in practical applications, which was evaluated herein by measuring the glucose yield in each hydrolysis cycle (Figure 10). As the number of uses increased, the glucose yield showed a slow decline and then became stable, whereas the initial glucose yield was $330.9 \mathrm{mg}$ glucose/g CMC and remained at $86.0 \%$ after 10 repeated uses. The loss of glucose yield may have been caused by the protein denaturation or cellulase leakage during the hydrolysis process [5]. Moreover, it is possible that a large number of reaction products were deposited on the surface of the substrate, thereby restricting the activity of the proteins. Here, the results suggest that immobilized enzymes can be used several times with a high glucose yield, indicating their potential in practical applications. 


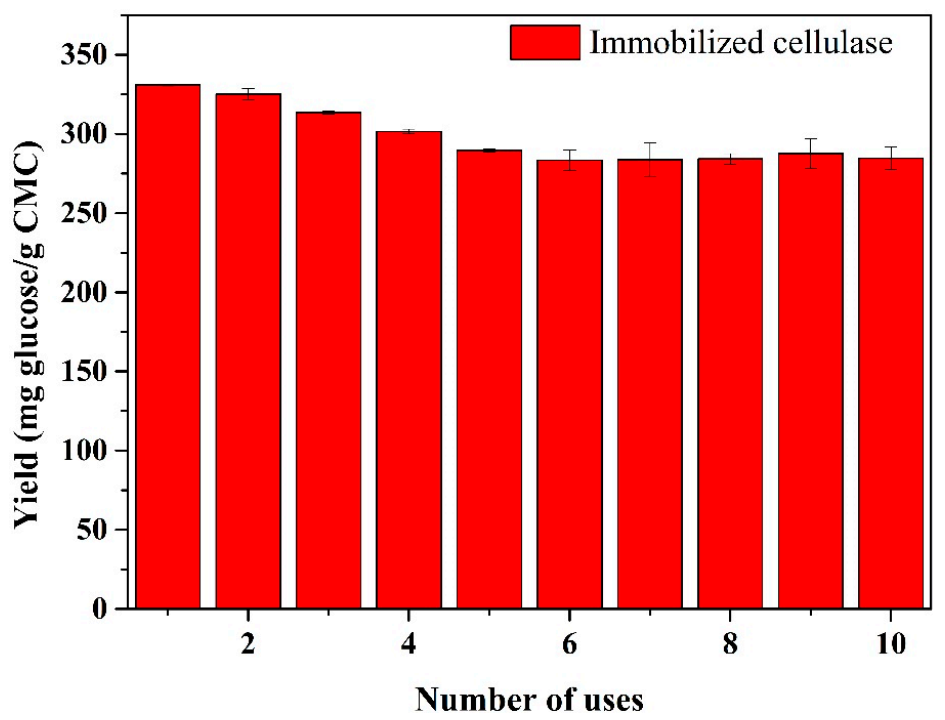

Figure 10. Effect of recycling on the glucose productivity of immobilized cellulase. Each cycle was performed at $\mathrm{pH} 4$ and $60{ }^{\circ} \mathrm{C}$ for $24 \mathrm{~h}$.

In addition, the immobilized cellulase was stored in a refrigerator at $4{ }^{\circ} \mathrm{C}$ for one month. Then, the activity was tested. The results showed that the relative activity of the immobilized cellulase was $90.36 \%$ of the initial value, indicating its good storage stability.

\section{Conclusions}

A chitosan/magnetic porous biochar support was successfully prepared by simple methods. Cellulase was immobilized onto the support by covalent bonding using the GA agent. Under the influence of $\mathrm{pH}$ and temperature, the relative activity trend of the immobilized enzyme was similar to that of the free enzyme. It seems that there were few alterations of the cellulase, and the optimum temperature and $\mathrm{pH}$ of both the immobilized and free enzymes were $60{ }^{\circ} \mathrm{C}$ and $\mathrm{pH} 4$. However, the immobilized cellulase showed high reusability: $86.0 \%$ of initial glucose productivity remained after 10 cycles. Therefore, the chitosan/magnetic porous biochar support has potential in practical applications based on the enzymatic performance of its immobilized cellulase, but it still needs further discussion.

Author Contributions: Conceptualization, J.Q.; data curation, J.Q.; investigation, H.M.; methodology, H.M.; supervision, J.Q.; validation, H.M.; writing—original draft, H.M.; writing—review and editing, H.M. and J.Q. All authors have read and agreed to the published version of the manuscript.

Funding: This research received no external funding.

Acknowledgments: We thank Chao Yang, Limin Zang and Eiichi Sakai's contribution to the analysis of the results. And we thank Komiyama and Wang for their help of VSM and BET test.

Conflicts of Interest: The authors declare no conflict of interest.

\section{References}

1. Alvira, P.; Tomás-Pejó, E.; Ballesteros, M.; Negro, M.J. Pretreatment technologies for an efficient bioethanol production process based on enzymatic hydrolysis: A review. Bioresour. Technol. 2010, 101, 4851-4861. [CrossRef]

2. Harun, R.; Danquah, M.K. Enzymatic hydrolysis of microalgal biomass for bioethanol production. Chem. Eng. J. 2011, 168, 1079-1084. [CrossRef]

3. Ho, S.H.; Huang, S.W.; Chen, C.Y.; Hasunuma, T.; Kondo, A.; Chang, J.S. Bioethanol production using carbohydrate-rich microalgae biomass as feedstock. Bioresour. Technol. 2013, 135, 191-198. [CrossRef]

4. Wood, T.M.; Bhat, K.M. Methods for measuring cellulase activities. Methods Enzymol. 1988, 160, 87-112. 
5. Zang, L.; Qiu, J.; Wu, X.; Zhang, W.; Sakai, E.; Wei, Y. Preparation of magnetic chitosan nanoparticles as support for cellulase immobilization. Ind. Eng. Chem. Res. 2014, 53, 3448-3454. [CrossRef]

6. Poorakbar, E.; Shafiee, A.; Saboury, A.A.; Rad, B.L.; Khoshnevisan, K.; Ma'mani, L.; Derakhshankhah, H.; Ganjali, M.R.; Hosseini, M. Synthesis of magnetic gold mesoporous silica nanoparticles core shell for cellulase enzyme immobilization: Improvement of enzymatic activity and thermal stability. Process Biochem. 2018, 71, 92-100. [CrossRef]

7. Woodley, J.M. Protein engineering of enzymes for process applications. Curr. Opin. Chem. Biol. 2013, 17, 310-316. [CrossRef] [PubMed]

8. Rodrigues, R.C.; Ortiz, C.; Berenguer-murcia, Á.; Torres, R.; Fernández-Lafuente, R. Modifying enzyme activity and selectivity by immobilization. Chem. Soc. Rev. 2013, 42, 6290-6307. [CrossRef] [PubMed]

9. Khoshnevisan, K.; Vakhshiteh, F.; Barkhi, M.; Baharifar, H.; Poor-Akbar, E.; Zari, N.; Stamatis, H.; Bordbar, A.K. Immobilization of cellulase enzyme onto magnetic nanoparticles: Applications and recent advances. Mol. Catal. 2017, 442, 66-73. [CrossRef]

10. Altinkaynak, C.; Tavlasoglu, S.; Özdemir, N.; Ocsoy, I. Enzyme and Microbial Technology A new generation approach in enzyme immobilization: Organic-inorganic hybrid nanoflowers with enhanced catalytic activity and stability. Enzyme Microb. Technol. 2016, 93-94, 105-112. [CrossRef]

11. Yang, C.; Mo, H.; Zang, L.; Chen, J.; Wang, Z.; Qiu, J. Surface functionalized natural inorganic nanorod for highly efficient cellulase immobilization. RSC Adv. 2016, 6, 76855-76860. [CrossRef]

12. Grewal, J.; Ahmad, R.; Khare, S.K. Development of cellulase-nanoconjugates with enhanced ionic liquid and thermal stability for in situ lignocellulose saccharification. Bioresour. Technol. 2017, 242, 236-243. [CrossRef] [PubMed]

13. Tully, J.; Yendluri, R.; Lvov, Y. Halloysite clay nanotubes for enzyme immobilization. Biomacromolecules 2016, 17, 615-621. [CrossRef] [PubMed]

14. Çalımlı, M.H.; Demirbaş, Ö.; Aygün, A.; Alma, M.H.; Nas, M.S.; Şen, F. Immobilization kinetics and mechanism of bovine serum albumin on diatomite clay from aqueous solutions. Appl. Water Sci. 2018, 8, 1-12. [CrossRef]

15. Naghdi, M.; Taheran, M.; Brar, S.K.; Kermanshahi-pour, A.; Verma, M.; Surampalli, R.Y. Fabrication of nanobiocatalyst using encapsulated laccase onto chitosan-nanobiochar composite. Int. J. Biol. Macromol. 2019, 124, 530-536. [CrossRef]

16. Avnir, D.; Braun, S.; Lev, O.; Ottolenghit, M. Enzymes and other proteins entrapped in sol-gel materials. Chem. Mater. 1994, 6, 1605-1614. [CrossRef]

17. Chen, B.; Qiu, J.; Mo, H.; Yu, Y.; Ito, K.; Sakai, E.; Feng, H. Synthesis of mesoporous silica with different pore sizes for cellulase immobilization: Pure physical adsorption. New J. Chem. 2017, 41, 9338-9345. [CrossRef]

18. Mehta, J.; Bhardwaj, N.; Bhardwaj, S.K.; Kim, K.H.; Deep, A. Recent advances in enzyme immobilization techniques: Metal-organic frameworks as novel substrates. Coord. Chem. Rev. 2016, 322, 30-40. [CrossRef]

19. Xu, W.; Sun, Z.; Meng, H.; Han, Y.; Wu, J.; Xu, J.; Xu, Y.; Zhang, X. Immobilization of cellulase proteins on zeolitic imidazolate framework (ZIF-8)/polyvinylidene fluoride hybrid membranes. New J. Chem. 2018, 42, 17429-17438. [CrossRef]

20. Cha, J.S.; Park, S.H.; Jung, S.; Ryu, C.; Jeon, J.; Shin, M.; Park, Y. Production and utilization of biochar: A review. J. Ind. Eng. Chem. 2016, 40, 1-15. [CrossRef]

21. Rehrah, D.; Bansode, R.R.; Hassan, O.; Ahmedna, M. Physico-chemical characterization of biochars from solid municipal waste for use in soil amendment. J. Anal. Appl. Pyrolysis 2016, 118, 42-53. [CrossRef]

22. Qambrani, N.A.; Rahman, M.M.; Won, S.; Shim, S.; Ra, C. Biochar properties and eco-friendly applications for climate change mitigation, waste management, and wastewater treatment: A review. Renew. Sustain. Energy Rev. 2017, 79, 255-273. [CrossRef]

23. Mian, M.M.; Liu, G.; Fu, B. Conversion of sewage sludge into environmental catalyst and microbial fuel cell electrode material: A review. Sci. Total Environ. 2019, 666, 525-539. [CrossRef] [PubMed]

24. Qian, K.; Kumar, A.; Zhang, H.; Bellmer, D.; Huhnke, R. Recent advances in utilization of biochar. Renew. Sustain. Energy Rev. 2015, 42, 1055-1064. [CrossRef]

25. Santos, M.P.F.; da Silva, J.F.; da Costa Ilhéu Fontan, R.; Bonomo, R.C.F.; Santos, L.S.; Veloso, C.M. New insight about the relationship between the main characteristics of precursor materials and activated carbon properties using multivariate analysis. Can. J. Chem. Eng. 2020, 98, 1501-1511. [CrossRef] 
26. Yang, X.; Ma, Y.; Li, L. $\beta$-Glucosidase from tartary buckwheat immobilization on bifunctionalized nano-magnetic iron oxide and its application in tea soup for aroma and flavonoid aglycone enhancement. Food Funct. 2019, 10, 5461-5472. [CrossRef] [PubMed]

27. Monteiro, R.R.C.; Neto, D.M.A.; Fechine, P.B.A.; Lopes, A.A.S.; Gonçalves, L.R.B.; Dos Santos, J.C.S.; de Souza, M.C.M.; Fernandez-Lafuente, R. Ethyl butyrate synthesis catalyzed by lipases a and b from candida antarctica immobilized onto magnetic nanoparticles. Improvement of biocatalysts' performance under ultrasonic irradiation. Int. J. Mol. Sci. 2019, 20, 5807. [CrossRef]

28. Karimi-Maleh, H.; Shafieizadeh, M.; Taher, M.A.; Opoku, F.; Kiarii, E.M.; Govender, P.P.; Ranjbari, S.; Rezapour, M.; Orooji, Y. The role of magnetite/graphene oxide nano-composite as a high-efficiency adsorbent for removal of phenazopyridine residues from water samples, an experimental/theoretical investigation. J. Mol. Liq. 2020, 298, 112040. [CrossRef]

29. Doustkhah, E.; Rostamnia, S.; Gholipour, B.; Zeynizadeh, B.; Baghban, A.; Luque, R. Design of chitosan-dithiocarbamate magnetically separable catalytic nanocomposites for greener aqueous oxidations at room temperature. Mol. Catal. 2017, 434, 7-15. [CrossRef]

30. Sánchez-Ramírez, J.; Martínez-Hernández, J.L.; Segura-Ceniceros, P.; López, G.; Saade, H.; Medina-Morales, M.A.; Ramos-González, R.; Aguilar, C.N.; Ilyina, A. Cellulases immobilization on chitosan-coated magnetic nanoparticles: Application for Agave Atrovirens lignocellulosic biomass hydrolysis. Bioprocess Biosyst. Eng. 2017, 40, 9-22. [CrossRef]

31. Ahmed, S.A.; Abdella, M.A.A.; El-Sherbiny, G.M.; Ibrahim, A.M.; El-Shamy, A.R.; Atalla, S.M.M.; Hassan, M.E. Catalytic, kinetic and thermal properties of free andimmobilized bacillus subtilis $-\mathrm{MK}_{1} \alpha$-amylase on chitosan-magnetic nanoparticles. Biotechnol. Rep. 2020, 26, e00443. [CrossRef] [PubMed]

32. de Oliveira, R.L.; da Silva, M.F.; da Silva, S.P.; de Araújo, A.C.V.; Cavalcanti, J.V.F.L.; Converti, A.; Porto, T.S. Fructo-oligosaccharides production by an Aspergillus aculeatus commercial enzyme preparation with fructosyltransferase activity covalently immobilized on $\mathrm{Fe}_{3} \mathrm{O}_{4}$-chitosan-magnetic nanoparticles. Int. J. Biol. Macromol. 2020, 150, 922-929. [CrossRef] [PubMed]

33. Galvão, W.S.; Pinheiro, B.B.; Golçalves, L.R.B.; de Mattos, M.C.; Fonseca, T.S.; Regis, T.; Zampieri, D.; dos Santos, J.C.S.; Costa, L.S.; Correa, M.A.; et al. Novel nanohybrid biocatalyst: Application in the kinetic resolution of secondary alcohols. J. Mater. Sci. 2018, 53, 14121-14137. [CrossRef]

34. Santos, J.C.S.D.; Barbosa, O.; Ortiz, C.; Berenguer-Murcia, A.; Rodrigues, R.C.; Fernández Lafuente, R. Importance of the support properties for immobilization or purification of enzymes. ChemCatChem 2015, 7, 2413-2432. [CrossRef]

35. Zaak, H.; Siar, E.; Kornecki, J.F.; Fernandez-lopez, L.; Pedrero, S.G.; Virgen-ortíz, J.J.; Fernandez-lafuente, R. Effect of immobilization rate and enzyme crowding on enzyme stability under different conditions. The case of lipase from Thermomyces lanuginosus immobilized on octyl agarose beads. Process Biochem. 2017, 56, 117-123. [CrossRef]

36. Baghban, A.; Heidarizadeh, M.; Doustkhah, E.; Rostamnia, S.; Rezaei, P.F. Covalently bonded pancreatic lipase onto the dithiocarbamate/chitosan-based magnetite: Stepwise fabrication of $\mathrm{Fe}_{3} \mathrm{O}_{4} @ \mathrm{CS} / \mathrm{NHCS}-\mathrm{Lip}$ as a novel and promising nanobiocatalyst. Int. J. Biol. Macromol. 2017, 103, 1194-1200. [CrossRef]

37. Fathi, Z.; Doustkhah, E.; Rostamnia, S.; Darvishi, F.; Ghodsi, A.; Ide, Y. Interaction of Yarrowia lipolytica lipase with dithiocarbamate modified magnetic carbon $\mathrm{Fe}_{3} \mathrm{O}_{4} @ \mathrm{C}-\mathrm{NHCS}_{2} \mathrm{H}$ core-shell nanoparticles. Int. J. Biol. Macromol. 2018, 117, 218-224. [CrossRef]

38. Chen, J.; Qiu, J.; Wang, B.; Feng, H.; Yu, Y.; Sakai, E. Manganese dioxide/biocarbon composites with superior performance in supercapacitors. J. Electroanal. Chem. 2017, 791, 159-166. [CrossRef]

39. Mo, H.; Qiu, J.; Yang, C.; Zang, L.; Sakai, E. Preparation and characterization of magnetic polyporous biochar for cellulase immobilization by physical adsorption. Cellulose 2020, 27, 4963-4973. [CrossRef]

40. Compton, S.J.; Jones, C.G. Mechanism of dye response and interference in the bradford protein assay. Anal. Biochem. 1985, 151, 369-374. [CrossRef]

41. Ghose, T.K. Measurement of cellulase activities. Pure Appl. Chem. 1987, 59, 257-268. [CrossRef]

42. Chen, J.; Qiu, J.; Wang, B.; Feng, H.; Ito, K.; Sakai, E. $\mathrm{Fe}_{3} \mathrm{O}_{4}$ /biocarbon composites with superior performance in supercapacitors. J. Electroanal. Chem. 2017, 804, 232-239. [CrossRef]

43. Asuha, S.; Zhao, S.; Wu, H.Y.; Song, L.; Tegus, O. One step synthesis of maghemite nanoparticles by direct thermal decomposition of Fe-urea complex and their properties. J. Alloys Compd. 2009, 472, 2008-2010. [CrossRef] 
44. Huff, M.D.; Kumar, S.; Lee, J.W. Comparative analysis of pinewood, peanut shell, and bamboo biomass derived biochars produced via hydrothermal conversion and pyrolysis. J. Environ. Manag. 2014, 146, 303-308. [CrossRef]

45. Zang, L.; Qiao, X.; Hu, L.; Yang, C.; Liu, Q.; Wei, C.; Qiu, J.; Mo, H.; Song, G.; Yang, J.; et al. Preparation and evaluation of coal fly ash/chitosan composites as magnetic supports for highly efficient cellulase immobilization and cellulose bioconversion. Polymers 2018, 10, 523. [CrossRef]

46. Butterfield, D.A.; Bhattacharyya, D.; Daunert, S.; Bachas, L. Catalytic biofunctional membranes containing site-specifically immobilized enzyme arrays: A review. J. Memb. Sci. 2001, 181, 29-37. [CrossRef]

47. geor Malar, C.; Muthulingam, S.; Kumar, K.S.; Kumar, A.; Parthiban, R. Review on surface modification of nanocarriers to overcome diffusion limitations: An enzyme immobilization aspect. Biochem. Eng. J. 2020, 158, 107574. [CrossRef]

48. Hanefeld, U.; Magner, E. Understanding enzyme immobilisation. Chem. Soc. Rev. 2009, 38, 453-468. [CrossRef]

49. Ying, L.; Kang, E.T.; Neoh, K.G. Covalent immobilization of glucose oxidase on microporous membranes prepared from poly(vinylidene fluoride) with grafted poly(acrylic acid) side chains. J. Memb. Sci. 2002, 208, 361-374. [CrossRef]

Publisher's Note: MDPI stays neutral with regard to jurisdictional claims in published maps and institutional affiliations.

(C) 2020 by the authors. Licensee MDPI, Basel, Switzerland. This article is an open access article distributed under the terms and conditions of the Creative Commons Attribution (CC BY) license (http://creativecommons.org/licenses/by/4.0/). 